\title{
A DECENTRALIZÁLT GEOTERMIKUS HŐELLÁTÁS ÉS A HŐSZIVATTYÚZÁS AKTUÁLIS KÉRDÉSEI
}

\section{CURRENT QUESTIONS OF DECENTRALIZED GEOTHERMAL HEAT SUPPLY AND HEAT PUMPING}

\author{
Ádám Béla ${ }^{1}$, Szanyi János ${ }^{2}$, Bencsik Attila ${ }^{3}$, Bozsó Gábor ${ }^{4}$, Pinjung Zsolt ${ }^{5}$ \\ ${ }^{1}$ PhD, a Magyar Hốszivattyú Szövetség elnöke, adam@hgd.hu \\ ${ }^{2}$ PhD, Szegedi Tudományegyetem Ásványtani, Geokémiai és Kőzettani Tanszék, szanyi@iif.u-szeged.hu \\ ${ }^{3}$ geológus, Geotermikus Szolgáltató Kft., bencsika@geo.u-szeged.hu \\ ${ }^{4}$ PhD, INNOGEO Kft., bozso.gabor@geo.u-szeged.hu \\ ${ }^{5}$ hidrogeológus-mérnök, P-MONT Kft., Szeged, pinjungzs@gmail.com
}

\begin{abstract}
ÖSSZEFOGLALÁS
Hazánk energiamérlegében a fütési-hűtési célú energiafelhasználás az összenergia-felhasználás mintegy 40\%-át teszi ki. Ennek túlnyomó része, közel 90\%-a földgázalapú. A megújuló energiák, különösen a geotermikus energia hasznosításával számottevően csökkenthető lenne a földgázimport. Szomorú, hogy még jelenleg is példákkal kell bizonyítani a sekély- (hőszivattyú) és mélygeotermia versenyképességét. A bemutatott esettanulmányokkal a döntéshozók figyelmét kívánjuk felhívni a geotermikus energia egyedi rendszerű, illetve a távhőellátásban rejlő gazdaságos alkalmazási lehetőségeire.
\end{abstract}

\section{ABSTRACT}

Current questions of decentralized geothermal heat supply and heat pumping total heating and cooling energy consumption accounts for about $40 \%$ of total energy use in Hungary's energy balance. The overwhelming part (nearly $90 \%$ ) of this usage is based on natural gas. Utilization of renewable energies, especially geothermal energy, could significantly reduce natural gas imports. It is sad that one still needs to recite real world examples to demonstrate the competitiveness of shallow (heat pump) and deep geothermal energy. With the case studies presented, we intend to draw the attention of the decision-makers to the economical applications of geothermal energy in individual system and in district heat supply.

Kulcsszavak: geotermikus energia, hőszivattyú, távhőszolgáltatás

Keywords: geothermal energy, heat pump, district heating supply 


\section{BEVEZETÉS}

A geotermikus energia megbízható, helyben rendelkezésre álló, részlegesen megújuló energiaforrás. Használatához jelentős gazdasági és környezeti előnyök társulnak, különösen a fütés-hütés terén. Annak bemutatására, hogyan bővíthető a geotermikus alapú hőszolgáltatás, vizsgáljuk meg, milyen a hazai hőenergia-szolgáltató szektor szerkezete, felvázolva a környezetvédelmi, gazdasági összefüggéseket, és a technológiában rejlő innovációs eredményeket és lehetőségeket.

Az energiaforrások közel negyven százalékát hőellátásra használjuk, ez Magyarországon 387 PJ/év hőenergia elóállítását jelenti, amelynek mintegy 88\%-a földgáz (340 PJ) és csak alig 12\%-a hazai megújuló energiaforrás (47 PJ), ebből geotermia (4,5 PJ), napenergia (0,25 PJ), biomassza (42,7 PJ) (Kurunczi, 2017). A földgáz több mint $80 \%$-a importból származik, ez évente mintegy 800 milliárd Ft kiadást jelent.

Höenergia helyben, fütsünk hatékonyabban hazai energiával! címmel 2015 októberében az MTA-n megtartott konferencián vázoltuk, hogyan lehetne a höpiacot optimalizálni mind nemzetgazdasági, mind fogyasztói szempontból (MTA et al., 2015).

Első feladat az energiahatékonyság növelése, a felhasznált energia csökkentése. Ezáltal a 800 milliárd forintot kitevő gázszámla 240 milliárddal csökkenhet csak attól, hogy épületeinket szigeteljük, és fütési rendszereinket korszerüsítjük. A közel négymillió ingatlan energiahatékonysági javítása minimum 100 PJ höigénycsökkenést jelent, ami szinkronban van a Nemzeti Épületenergetikai Stratégia céljaival is. A szükséges beruházási forrás - $3 \mathrm{M} \mathrm{Ft/ingatlan} \mathrm{fajlagos} \mathrm{értékkel}$ számolva - 12 ezer milliárd Ft, negyvenéves program esetén 300 milliárd Ft/év, ami 150 milliárd Ft/év támogatási összeget (50\%) kíván.

Következő lépés a hazai primer energiafajták részesedésének növelése a hazai energiamixben. Hazánk kihasználatlan természeti adottságai (geotermikus energia, napenergia), mező- és erdőgazdálkodási melléktermékei, kommunális hulladékai legalább 250 PJ-nyi decentralizált, helyben hasznosulni képes, saját energiaforrást jelentenek. Szakértők és szakmai szervezetek közremüködésével negyvenéves programot állítottunk össze, amelynek végén az energiahatékonyság növelése miatt 287,5 PJ-ra lecsökkent hazai hőellátás energiahordozó-struktúrája az alábbiak szerint alakulna:

- geotermia: 52,6 PJ (ebből 10 PJ hőszivattyú) - 18\%

- napenergia: $10,25 \mathrm{PJ}-4 \%$

- biomassza: $135,7 \mathrm{PJ}-47 \%$

- földgáz: $89 \mathrm{PJ}\left(2,65 \mathrm{Mrd} \mathrm{m}^{3} / \mathrm{é}\right)$ - 31\%

A terv megvalósításának éves költsége hozzávetőleg 150 Mrd Ft, ami 50\%-os támogatás esetén 75 Mrd Ft állami hozzájárulást igényelne évente. A helyi hul- 
ladékból származó és megújuló energiák elóállítási költsége - működő projektek alapján - átlagosan is legalább 30\%-kal elmarad a földgáz beszerzési árától, ami 265 milliárdos helyi energia-előállítási költséget, azaz további 110 milliárdos megtakarítást jelentene a fogyasztók számára, valamint mintegy $3,5 \mathrm{M} \mathrm{t} \mathrm{CO}_{2} / \mathrm{év}$ kibocsátáscsökkenést eredményezne fenntartható módon!

Összehasonlításként például a hőszivattyú esetében a hazai tervek 2010-ben is ehhez igazodva határozták meg a Megújuló Energia Cselekvési Tervben a hőszivattyús energiatermelés nagyfokú növelését 0,25 PJ értékről 5,99 PJ értékre. Az alátámasztásként felsorolt készletbecslések 15-23 PJ közé prognosztizálták a sekély földhő készletét. Tehát ehhez képest a 2020-ra tervezett 5,99 PJ hőszivattyús földhőfelhasználás reális tervnek volt mondható, míg a felvázolt negyvenéves ütemben a 10 PJ-os cél határozottan visszafogott.

Sajnálatosan a 2020-as terv megvalósítására nincs már komoly esély, tekintettel az időarányos eredményekre. Ennek a helyzetnek számos oka van: a megújuló energia alkalmazásának támogatása energiapolitikai szinten elmaradt, a pályázatok nem folyamatosak, az energiaárak (rezsicsökkentés) nem szolgálják a hőszivattyús technológia terjedését, valamint a hőszivattyús technológia „relatív bonyolultsága” például egy napelemes rendszerhez viszonyítva az érdeklődőket is „,megszüri”, és az alkalmazás javasolt formája az új épületeknél szintén beszükíti a piaci mozgásteret. Mindezek fényében a jelenlegi höszivattyús energiatermelés $0,5-1,0$ PJ közötti lehet. Ez a lehetőségeink 5\%-a körüli kihasználása, amely mögött jelentős a levegő-víz hőszivattyúk elmúlt évekbeli elterjedése.

A geotermikus energia hasznosításában rejlő lehetőségek bemutatására elsőként a höszivattyús alkalmazások közül említünk néhány sikeres példát, majd a mély geotermikus rendszerek üzembiztonságát növelő kutatás-fejlesztési projektre mutatunk példát.

\section{HŐSZIVATTYÚ ALKALMAZÁSÁNAK ALAPELVEI}

A hőszivattyús technológia elsősorban az új épületek fütési és hütési igényéhez javasolt. Ennek indoka az, hogy ezeknél az épületeknél már a jó szigetelések miatt kicsi a hőigény, alacsony hőmérsékletü, felület fütő-hütő rendszereket lehet beépíteni, hőszivattyúval biztosítani lehet a felmerülő automatizálási igényt, így a fajlagos költség alacsonyabb, különösen, ha napelemes rendszerrel van kombinálva a hőszivattyú. Ha a fenti követelményeket egy épületfelújítás is kielégíti, akkor természetesen ott is javasolható a hőszivattyú a földgáz kiváltására.

További szempont, hogy az éves üzemeltetési kihasználtság minél nagyobb legyen fütésben és hütésben is. Emellett ne csak a teljesítmény csúcsigényére méretezzünk, hanem az éves fütési és hütési energia mennyiségének igényére is, 
lehetőleg havi elosztásban. Vizsgálni kell továbbá a bivalens üzem lehetőségét is (70-80\% hőszivattyúzás, csúcsigényre például fütőbetét vagy kazán alkalmazása, különösen, ha már korábban beépítették).

A hőszivattyús primer energiaforrásokból azt kell alkalmazni, amelyiknek az adott helyszínen a legjobb ár-érték arányú megválasztása lehetséges. Földhőt ott, ahol a fúrási körülmények könnyủek, talajvizet ott, ahol az biztonságos hozamú, a rétegvizet hasonló elv alapján, elfolyó „hulladékvizet” ott, ahol rendelkezésre áll, és végül ezek hiányában a levegős hőszivattyú is megoldás lehet.

\subsection{Példák projektekre és azokból levonható következtetésekre}

A családi házaknál a höigény a legújabb épületenergetikai előírások miatt drasztikusan lecsökkent. Manapság a 150-200 nm-es házak höigénye sem haladja meg a 8-10 kW-ot, sőt az alacsony energiájú vagy passzívházak igénye 3-6 kW körül van. Ezekhez még földhőszonda esetén is elég 1-2 szonda lefúrása, vagy 30-50 l/ perces vízhozamot „garantálni” vízkúttal. Itt nem szabad elfelejteni, hogy a víz nyelőkútba való visszasajtolásáról is gondoskodni kell. Ebben az esetben már fontos a kútpár gazdasági vizsgálata a szondával összehasonlítva. Emellett a nyelés kockázata és a vízminőség, vízhozam hosszú távú prognosztizálása is jelent kockázatot. Tehát fontos az előzetes geológiai és hidrogeológiai felmérés, információértékelés.

Az említett lehetőségek mellett, sok esetben a fúrási beruházási költség miatt a levegős hőszivattyút választják. E megoldás kiválasztásakor viszont figyelni kell a méretezési hőmérséklet melletti teljesítményre, amit a gyártók teljesítménygörbéje megad. Tekintettel a téli hideg levegőre, kevésbé hatékonyak, mint más szondás vagy vizes primer hőnyerős hőszivattyúk, ezért nem árt a teljesítmény 20-30\%-os „túlméretezése”. A fajlagos költségek ezeknél a kis családi házas rendszereknél a legnagyobbak, de ezek is folyamatosan csökkennek a technológia fejlesztése révén (nettó 300-400 E Ft/kW). Élettartamuk legalább huszonöt-harminc év, a hőnyerő szondáké „örök”. Különösen, ha a fütési és hütési igény kiegyenlített, mert így a földhő regenerálódása biztosítva van az éves ciklusokban.

Társasházaknál az utóbbi időben a szondás megoldás mellett a levegős hőszivattyúk terjedtek el. Különösen figyelni kell ezeknél a ventilátoros külső egység elhelyezésére a zajszennyezés miatt. A legmodernebb kompakt hőszivattyúk már ezt a problémát is kiküszöbölik (1. ábra).

- 11 lakás

- $1000 \mathrm{~m}^{2}$ fütött-hütött alapterület

- $11 \mathrm{~kW}$ fütési igény

- $11 \mathrm{~kW}$ használati meleg víz (HMV)

- $22 \mathrm{~kW}(2 \times 11 \mathrm{~kW})$ hőszivattyú

- $30 \mathrm{~m}^{2}$ napkollektor központi HMV termelésre (éves szükséglet $\sim 60 \%$-a) 


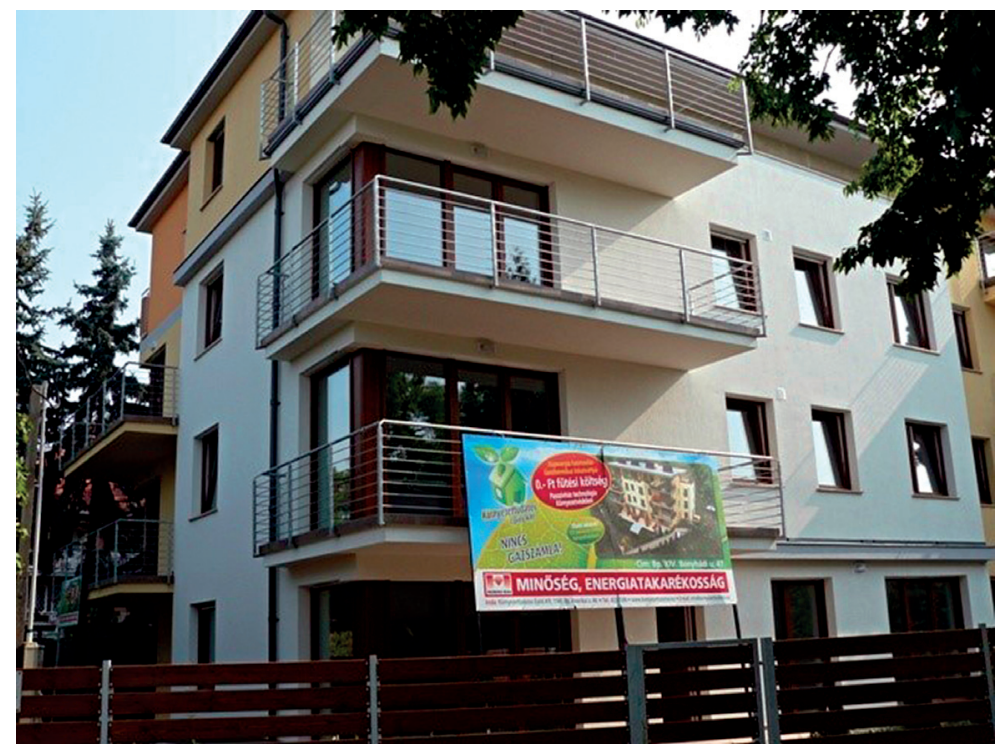

1. ábra. Budapest XIV. ker., Bonyhádi u. 47., passzívház

Érdemes megemlíteni a társasházak esetében a tervezési koncepciókat: lakásonként külön hőellátás vagy zónánkénti közös ellátás egyedi szabályozással. A megoldásokat a lakók igényei befolyásolhatják. A bekerülési költségek erősen függenek a kiválasztott koncepciótól és az automatizálás mértékétől (nettó 150$200 \mathrm{E} \mathrm{Ft/kW} \mathrm{lakásonként).}$

\subsection{Irodaházak, üzletházak, sportközpontok stb.}

Jellemzöjük a nagy energiaigény (akár több MW), különösen figyelni kell a nagy hütési igényre. Törekedni kell a fütés/hütés kiegyenlített méretezésére. Ez, különösen a szondás rendszereknél, próbafúrásokban végzett szondatesztekkel és szoftveres méretezéssel biztonságosan megoldható. Sajnos ezt a beruházók nem mindig igénylik a tervezés időszakában, pedig a beruházási és a későbbi üzemeltetési költség csökkentésének egyik biztos megoldása. A másik szakmai követelmény, hogy az elkészült földhős szondamezőket ún. monitoring szondákkal ellenőrizzük. Ezekben a szondákban hőmérsékletfüzérekkel a teljes üzemidőben, évekig tudjuk a szondamező müködését ellenőrizni, és igazolni egy korábbi méretezés helyességét (2. ábra).

- $320 \mathrm{~kW}$ fütési igény

- 330 kW hütési igény

- $55 \mathrm{db} \times 125 \mathrm{~m}$ földhőszonda 

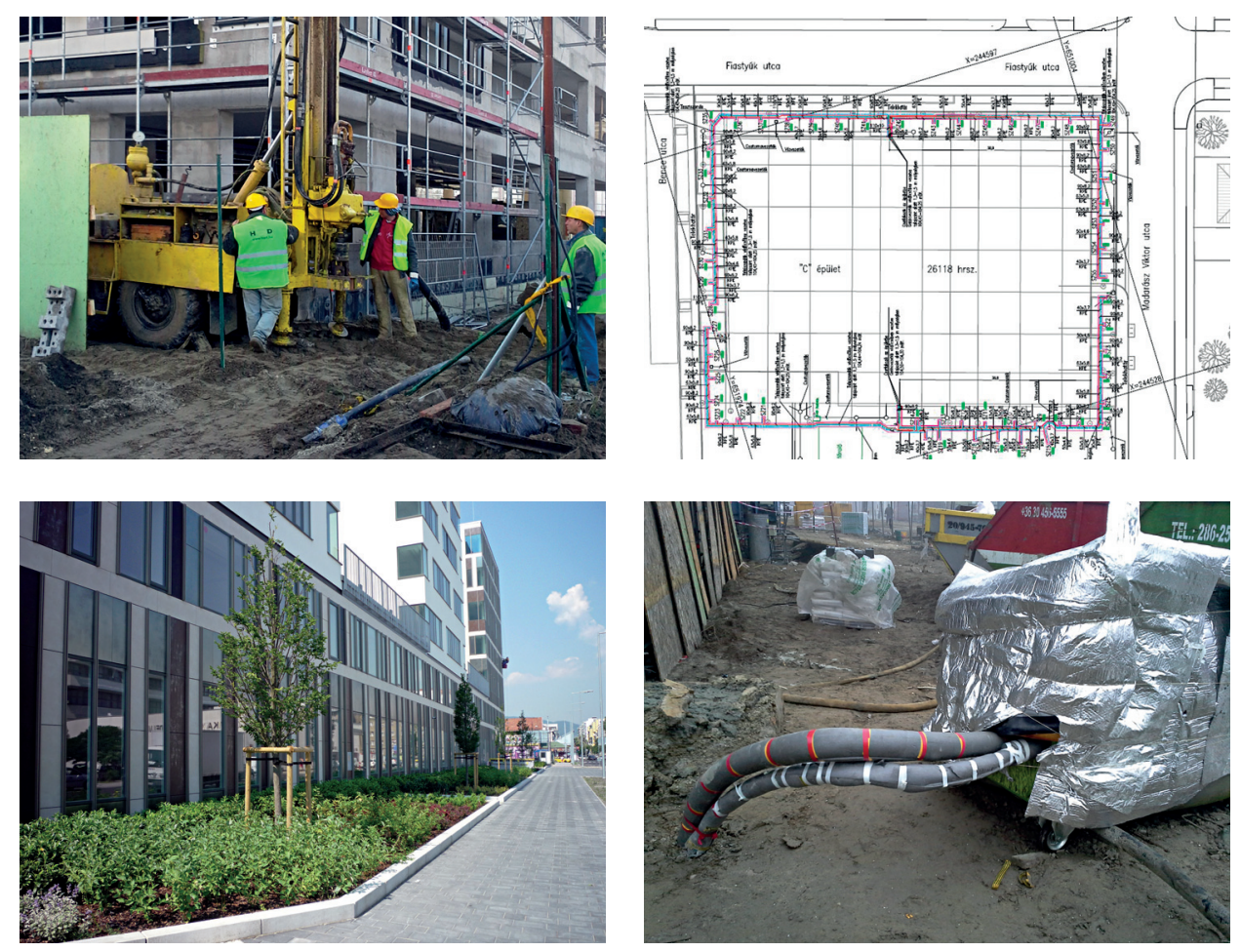

2. ábra. A váci Greens irodaépület

Itt kell megemlíteni, hogy egy hőszivattyús rendszer kiegyensúlyozott müködése nagyban függ a szekunder hőleadó oldal tervezésétől és megvalósításától, valamint az üzemeltetési körülményektől. Szigorúan be kell tartani a tervezési és méretezési paramétereket. Figyelni kell az épületek tájolására, az ebből következő hőterhelésekre, és ennek megfelelően zónaszabályozásokkal kell a helyi hőigényeket kezelni. Maga a primer hőszolgáltató hőszivattyú a puffer tárolóra dolgozva a végfelhasználónál csak „lassú fütés-hütés változtatásokat” képes megvalósítani, ezért sok esetben az egyidejü fütési-hütési igény miatt ún. „szimultán 4 csöves” rendszereket kell tervezni.

A cikk terjedelmi korlátai miatt további lényeges szempontok felsorolásától eltekintünk. Megállapítható, hogy az utóbbi években a nagy hőszivattyús rendszerek tervezésében és kivitelezésében jelentős előrelépés történt a megbízhatóság területén. Ennek egyik eredménye, hogy a fajlagos költségek itt is csökkentek (szondás primer oldal höszivattyús höközponttal együtt a helyi fúrási körülményektől függően nettó $300 \mathrm{E} \mathrm{FT/kW).} \mathrm{Kiemelendő} \mathrm{a} \mathrm{hőszivattyús} \mathrm{rendszerek} \mathrm{környezet-}$ védelmi előnye, a $\mathrm{CO}_{2}$-kibocsátás megtakarítása, ami fontos a különböző ,zöld beruházási minősítésekhez". Ma már ez a cél hőszivattyú nélkül alig érhető el. 


\subsection{Elfolyó termálvizek hőszivattyús kaszkád hasznosítása}

Ahhoz képest, hogy a hazai termálkapacitás mekkora, az elfolyó vizek hőszivatytyús hasznosítása minimális. Ennek több oka is van: a visszasajtolás szabályozása nem kiszámítható, a hőforrás nem mindig ott van, ahol a hőpiac igénye, a termálvizek magasabb hőmérsékletére egyedileg tervezett hőszivattyúk kellenek, és ezért az áruk jóval magasabb stb. Ennek ellenére a jövőben ezen a területen is elörelépés várható, mert már vannak pozitív referenciák (3. ábra):

- termálvíz-hőcserélő $1300 \mathrm{~kW}$

- $61 / 42{ }^{\circ} \mathrm{C}$ primer és $59 / 40{ }^{\circ} \mathrm{C}$ szekunder hölépcső

- elfolyó termálvíz $40{ }^{\circ} \mathrm{C}$ és $15 \mathrm{~m}^{3} / \mathrm{h}$

- 7 ingatlan kiszolgálása

- szekunder elöremenő $52{ }^{\circ} \mathrm{C}$

- I. fokozat: $418 \mathrm{~kW}\left(\mathrm{COP}^{*} 5,15\right)$

- II. fokozat: $243 \mathrm{~kW}$ (COP 4)

- I. fokozat: $40 / 25^{\circ} \mathrm{C}$ hőcserélő és $33 / 18^{\circ} \mathrm{C} \mathrm{HP}{ }^{* *}$ hőlépcső

- II. fokozat: $20 / 9^{\circ} \mathrm{C}$ höcserélő és $17 / 6^{\circ} \mathrm{C}$ HP hölépcső

* COP: megmutatja, hogy egy höszivattyú $1 \mathrm{~kW}$ elektromos áramból hány $\mathrm{kW}$ höenergiát tud elöállitani

${ }^{* *} H P$ : höszivattyú

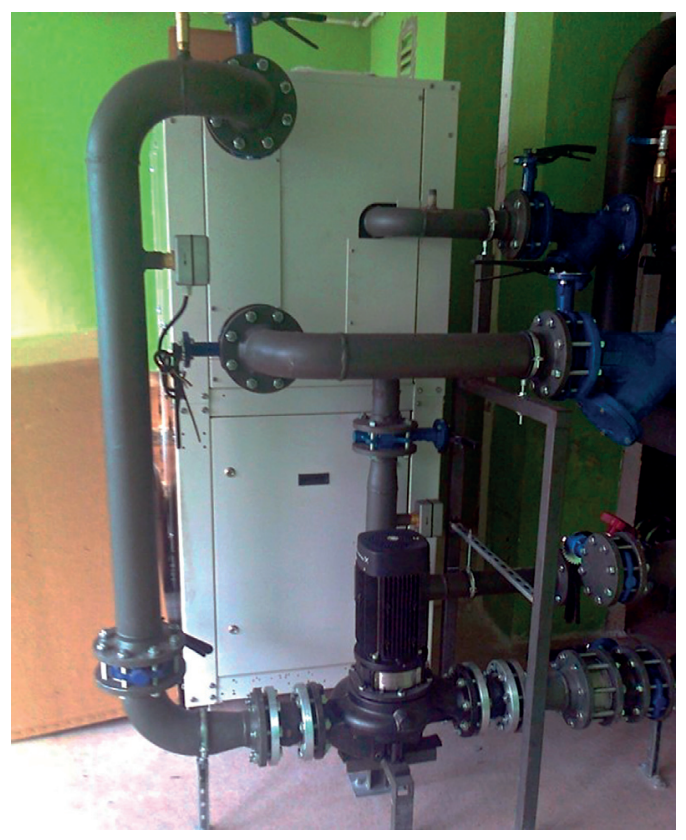

3. ábra. Mórahalom termál kaszkádrendszer I. ütem 


\subsection{A hőszivattyúzás fejlesztési innovációs lehetőségei}

A hőszivattyús technológia elterjedését, alkalmazásának előnyeit számos EU-tagállam szorgalmazza, és sikeresen beépítette országának energiapolitikájába. Az Európai Hőszivattyú Szövetség (EHPA) sikeresen képviseli az Európai Bizottságnál a technológia terjesztésének programját, erröl éves szinten statisztikai jelentést ad ki. Ebben látható, hogy a hőszivattyúzásban élen járó országok (Németország, Ausztria, Svájc és a skandináv államok) mint piacvezetők nagyságrendekkel nagyobb forgalmazást és kutatás-fejlesztést végeznek, mint a hazai hőszivattyús cégek, annak ellenére, hogy geotermikus adottságaik rosszabbak a köztudottan jó magyar geotermikus helyzetnél. Ennek oka, hogy energiapolitikájukban a fosszilis energiahordozók fütési célú felhasználásának drasztikus csökkentését képviselik, és jelentős forrásokat fordítanak innovációra.

Új eredmények vannak a hütőközegek fejlesztésében, a kompresszorok hatékonyságának növelésében, terjed az inverteres szabályozás, az expanziós szeleppel szabályozás szintén javítja a hatásfokot (COP: 4,5-5,0). Terjed a komplexitás: a hőszivattyú-szolgáltatáshoz, igényhez igazodó kiválasztás (fütés-hütés, használati meleg víz), akár dupla hőcserélő, desuperheater alkalmazása, távvezérlés okostelefonról, ergonómiai fejlesztések stb.

Ma egy korszerü hőszivattyú akár a hütőszekrény mellé is kerülhet, mert a zajszintje a számítógépekével vethető össze.

\section{MÉLYGEOTERMIA}

Hazánk geotermikus adottságaival nem kívánunk részletesen foglalkozni, megtette ezt korábban számos szerző és mi magunk is (Dövényi-Horváth, 1988; Szanyi-Kovács, 2010; Horváth et al., 2015). Magyarországon az üzemelö termálkutak mintegy 60\%-a felső pannóniai korú vízadókból termel, leginkább az 1000-2200 m közötti mélységtartományból.

Jelen tanulmányban a geotermikus energia távhőszolgáltatási célú hasznosítása áll a középpontban. Két szegedi projektet vizsgálunk, az egyik egy müködö rendszer, a másik egy létesítés alatt álló K+F-projekt keretei között megépülő kútpár (4. ábra). Mindkét projektben visszasajtolják a lefütött vizet. A visszasajtolás során a rendszer természetes utánpótlódását növeljük, segítve a rezervoár nyomásának fenntartását, valamint a felszíni hő- és kémiai szenynyezések megelőzését. Visszasajtoló-termelő kútpárok, kúthármasok távolságának és a szürőzött szakaszok mélységének tervezésénél gazdaságossági szempontokat is figyelembe kell vennünk. Minél messzebb van egymástól a termelő- és a visszasajtolókút, annál nagyobbak lesznek a felszíni csőhálózat építésének költségei, illetve ehhez hasonlóan minél mélyebb a visszasajtoló- 
kút, annál nagyobbak lesznek a fúrás költségei. A fúrási technika fejlődésével lehetővé vált ferde fúrások kivitelezése is. Ennek a technikának nagy előnye, hogy a vízadó rétegsort nagyobb látszólagos vastagságban harántolja (jobb lesz a visszasajtolókút nyelőképessége), illetve a kútfejek és a hőközpontok közelsége miatt rövidebb felszíni csővezeték-hálózat kiépítése szükséges, továbbá a termelö-visszasajtoló rendszer gépészeti elemei azonos telephelyen építhetők fel, így könnyebben elvégezhető a kutak és felszíni berendezések folyamatos, tervszerü karbantartása.

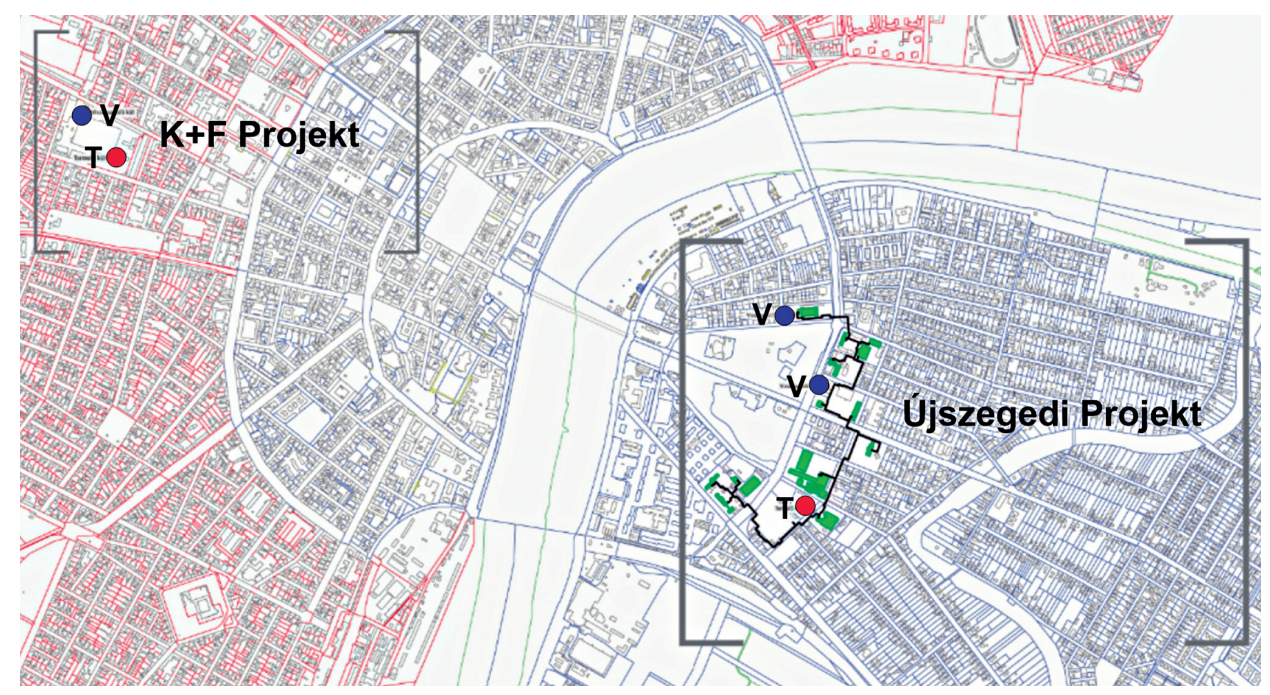

4. ábra. Szegedi projekthelyszínek (T: termelö-, V: visszasajtolókút)

\subsection{A szegedi geotermikus projekt tervezése}

Szegeden az 1960-as évek óta van hagyománya a geotermikus távhőszolgáltatásnak. Az üzemeltetés 2015 óta tekinthető fenntarthatónak, ekkor helyezték üzembe az újszegedi és a belvárosi termálrendszert egy-egy termelö- és két-két visszasajtolókúttal. A termelőkutakat 1950 m-es, míg a visszasajtolókutakat 1750 és 1300 m-es talpmélységgel mélyítették. Mindkét rendszer 4,5 $\mathrm{MW}_{\text {th }}$ teljesítményü, ahol a kifolyó víz hőmérséklete $90^{\circ} \mathrm{C}$, átlagos hozama $1200 \mathrm{l} / \mathrm{perc}$.

A vizsgált, kivitelezés alatt álló rendszer tervezéséhez elsősorban ezen kutak üzemelési tapasztalatait és korábbi kutak vízföldtani naplóit használtuk fel. Mivel Szeged térsége szénhidrogénipari szempontból jelentősen megkutatott, lehetőségünk volt a kutak helykijelöléséhez 3D szeizmikus értelmezést kérni a GEOMEGA Kft.-től a regionális vízadó rétegek meghatározására. 
A várható hidrogeológiai paraméterek meghatározásához a meglévő kutakba nyomásmérő szondákat helyezve pulzációs szivattyútesztet végeztünk, amelyet Gyenese István értékelt ki. A pulzációs tesztből kapott eredmények közel azonosak voltak az egykutas tesztek eredményeivel, igazolva a vízadók regionális folytonosságát.

Ezt követően került sor az új termelőkút és a ferde visszasajtolókút helyének kijelölésére. A termelőkút mélyítése során magmintákat vettünk, amelyeket részletes petrográfiai és hidrogeológiai vizsgálatnak vetettünk alá. Ennek során egyebek mellett elem- és ásványosösszetétel-vizsgálatokat végeztünk, különös tekintettel a pórusokat kitöltő ásványfázisokra. Ezt követően elvégeztük a karotázsszelvényekre, valamint a geokémiai és ásványos összetételre vonatkozó adatok statisztikai alapú összehasonlítását. Az adatok ismeretében kiválasztottuk a kevés duzzadó agyagásványt és szerves anyagot tartalmazó homokrétegeket, amelyek legalkalmasabbak a visszasajtolásra. Jelenleg a visszasajtolókút mélyítése zajlik.

\section{2. Üzemelő projekt optimalizálása}

A meglévő geotermikus rendszer hatékonyabb üzemeltetése szempontjából vizsgáltuk a felszíni és felszín alatti létesítményeket. A vizsgálatokat elsősorban az újszegedi geotermikus rendszeren végeztük. Ennek kezdetekor hetvenegy mintavételi pontot alakítottunk ki a geotermikus rendszeren. Több körben, különbözö üzemi paraméterek mellett (fütési szezon közben és előtt is) vett mintákon vízkémiai és bakteriológiai vizsgálatokat végeztünk (Varga et al., 2019). Üzemeltetés közben a speciálisan kialakított, magas hőmérsékletre és a jellemző nyomásviszonyokra kalibrált geokémiai szondarendszer segítségével folyamatosan detektáltuk a nyomás, a hőmérséklet, a pH és a vezetőképesség értékeit. A kapott adatok alapján az ilyen extrémnek tekinthető kémiai környezetben általánosan még nem alkalmazott ipari szondák üzemeltetési paramétereinek validálása, optimalizálása folyamatban van.

Ezzel párhuzamosan a felszíni rendszerben az üzemeltetés előző három évében és a szondák beépítése után in-situ keletkezett ásványkiválásokat mintáztuk és tanulmányoztuk. Az egyéves időtartam alatt a kiválásokból begyüjtött mintegy negyven minta minden esetben szinte teljes egészében kalcium-karbonát (kalcit), és a jelentősen eltérő makroszkopikus tulajdonságoktól (rétegek színe, szemcseösszetétel) függetlenül kémiailag és ásványtanilag is homogénnek tekinthető (5. ábra). Három, a rendszert érintő jelentős kiválási problémához kapcsolódó megfigyelést tudtunk tenni.

1. A rendszer belső fémfelületein a kiválások képződése rendkívül lassú addig, amíg egy $1 \mathrm{~mm}$ vastagságú kalcitréteg ki nem alakul, a réteg létrejötte után viszont - feltételezhetően a létrejött kristálynövekedési gócok mi- 
att - robbanásszerü a kiválás, extrém gyorsasággal (akár napi több mm-es vastagsággal) fejlődik a kalcitréteg, ami nyilvánvaló üzemeltetési gondot jelent.

2. A fütési szezon végi leállást követően legtöbbször egy vékony, sötétebb, alapvetően vas- és/vagy szervesanyag-tartalmú kéreg alakul ki azokban az esetekben, ahol a rendszer üzemi vízszintje lecsökkent, és a bejutó levegö oxidatív környezetet teremtett, sok esetben az öszi újraindításkor a kristály növekedése onnan folytatódik, ahol korábban abbamaradt, azaz a kalcit képződése nem lassul. Azokban az esetekben viszont, ahol az oxidatív körülmények között keletkezett barna színü kéreg vastagsága eléri vagy meghaladja a kb. $1 \mathrm{~mm}$-t, a kristályosodás a fémfelülethez hasonlóan újra lassú ütemü. Azokban az esetekben, ahol a sötét rétegek nem tartalmaznak sem szervetlen vas, sem szerves fázisokat, valószínüsítjük, hogy alacsonyabb hőfokon nem áramló környezetben, más laporientációjú kristályok fejlődnek, ekkor a kiválás változatlan ütemmel fejlődik.

3. A kalcitkristályok között olykor megfigyelhetők kvarchomok szemcsék és foszfortartalmú kiválások. Az előbbi a rétegből, az utóbbi az inhibitorból származhat.

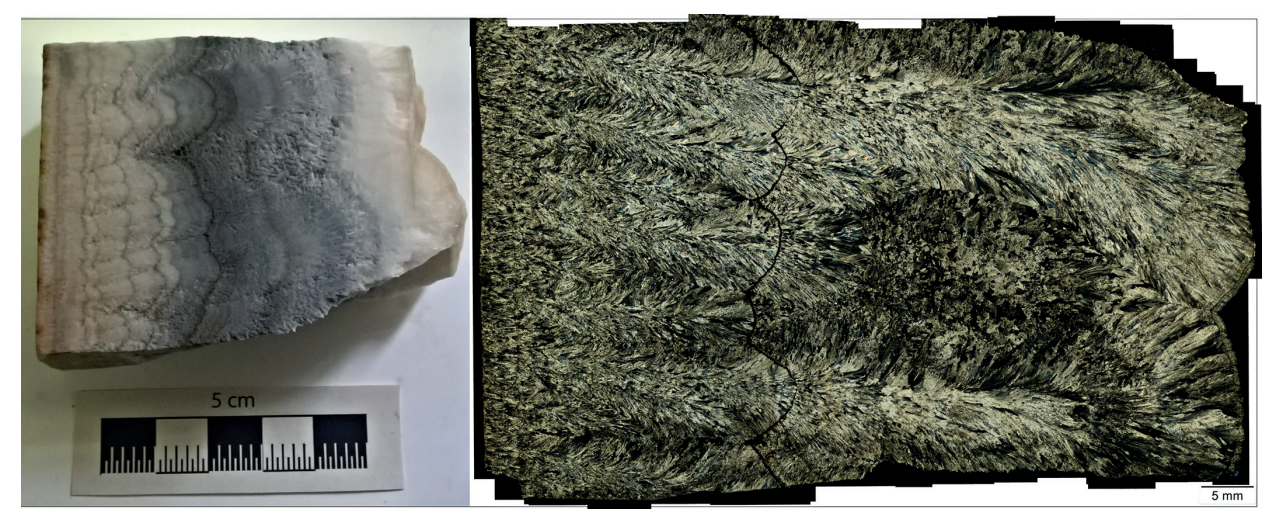

5. ábra. Ásványkiválás makroszkópos és csiszolati képe

Bár az eredmények kiértékelése még nem fejeződött be, és a rendszer vizsgálatát a következö fütési idény alatt is folytatjuk, néhány fontos következtetést már levontunk. Egyrészt a felszíni rendszer kismértékủ módosítását javasoltuk az ásványkiválások mértékének csökkentésére, másrészt új inhibitor használatát kezdeményeztük. Továbbá megállapítottuk, hogy teljesen zárt rendszerben az előforduló ásványkiválások és korrozív folyamatok jelentős mértékben csökkenthetők. A belvárosi rendszer termelö- és visszasajtolókútjainak el- 
helyezése ennek kipróbálását tette lehetővé. A rendszert üzemeltető cég egy

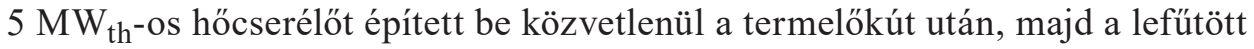
vizet azonnal a visszasajtolókutakba pumpálja. Már egy fél fútési szezon alatt érezhetően nőtt a kihelyezhető hőenergia mértéke, és csökkentek a karbantartási költségek.

Mindezen eredményeket Szeged város geotermikustávhö-fejlesztésében kívánjuk felhasználni, ahol a közeljövőben kilenc geotermikus rendszer (9 termelö- +18 visszasajtolókút) építése kezdődik meg (6. ábra). A városi távhőrendszer 28000 lakást és mintegy 500 középületet lát el 23 höközpontból, $224 \mathrm{MW}_{\text {th }}$ összteljesítménnyel. A kilenc geotermikus rendszer egy-egy hőközponthoz csatlakozik, és azok éves hőigényét 40-50\%-ban tudja majd kielégíteni. Ha az épületek energetikai korszerüsítése megtörténne, ez az érték akár a 90\%-ot is elérhetné (Osvald et al., 2017).

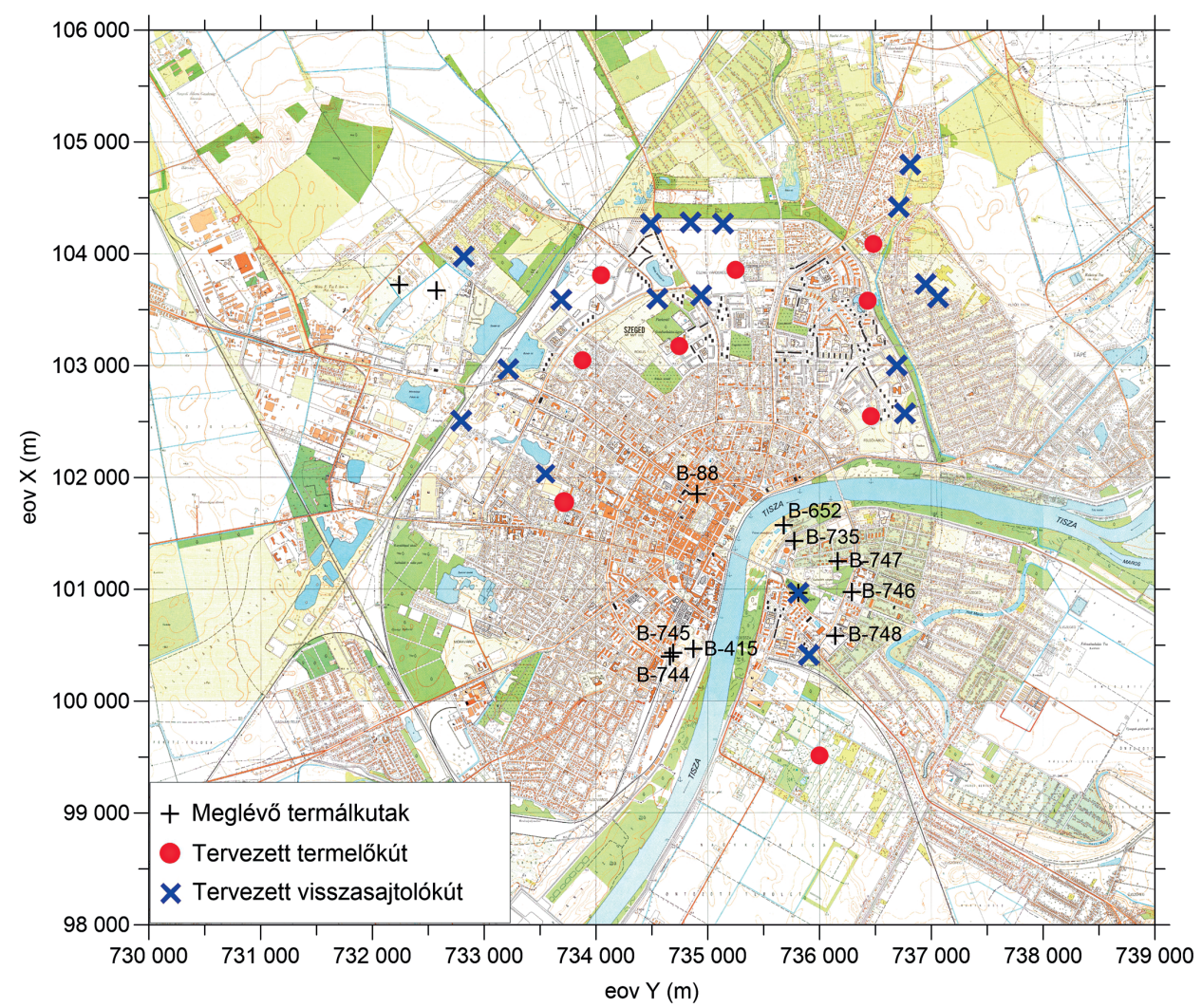

6. ábra. Meglévő és tervezett termálkutak Szeged belterületén 


\section{4. ÖSSZEFOGLALÁS}

Egyértelmüen kijelenthetjük, a hazai fütés-hütés üzletágban a megújuló energiáknak, különösen a sekély és mély geotermikus energiának kulcsszerepe lehet. Nemzetközi eredményei igazolják, és a hőszivattyús technológia a modern épületgépészet és életmód fontos elemévé vált. A hazai szakemberállomány az utóbbi években bizonyította, hogy a hőszivattyús technológia tervezésére és kivitelezésére, üzemeltetésére felkészült, és igény esetén a nagyobb ütemü terjedést is ki tudja szolgálni.

A bemutatott projektek azt sugallják, hogy a geotermikus szektor fejlődése jó úton halad, de különösen a mélygeotermia esetében sajnos nem így van. A hatékony fejlesztést hátráltatja a szétdarabolt hatósági ügyintézés, a szakmaiság háttérbe szorulása a döntési folyamatokban. A háttérben a szakma leépülése zajlik, alig van fúrási kapacitás. A geotermikus hasznosítók, különösen az önkormányzatok az üzemeltetési problémáikkal teljesen magukra maradtak. Mindezek növekvő kockázatot, a sikertelen projektek növekvő számát vetítik előre.

A felvázolt koncepció Fütsünk kevesebbet, olcsóbban, hazai energiával! (Kurunczi, 2017) megvalósításához elsősorban kormányzati akarat kell. Itt az ideje, hogy az állam elkezdjen felelős tulajdonosként gazdálkodni a geotermikus energiával.

\section{KÖSZÖNETNYILVÁNÍTÁS}

A mélygeotermikus projekt vizsgálatai a GINOP-2.1.1-15.2016.00970 számú pályázat támogatásával, az INNOGEO Kft., Szegedi Tudományegyetem Ásványtani, Geokémiai és Kőzettani Tanszék, a Geotermikus Szolgáltató Kft., a GEOMEGA Kft. és a GeoLog Kft. jelentéseinek felhasználásával készültek.

\section{IRODALOM}

Dövényi P. - Horváth F. (1988): A Review of Temperature, Thermal Conductivity, and Heat Flow Data for the Pannonian Basin. In: Royden, L. H. - Horváth F. (eds.): The Pannonian Basin. A Study in Basin Evolution. American Association of Petroleum Geologists Memoir, 45, 195233.

Horváth F. - Musitz B. - Balázs A. et al. (2015): Evolution of the Pannonian Basin and Its Geothermal Resources. Geothermics, 53, 328-352. DOI: 10.1016/j.geothermics.2014.07.009, https:// www.researchgate.net/publication/264789043_Evolution_of_the_Pannonian_basin_and_its_ geothermal_resources

Kurunczi M. (2017): Hőenergia helyben - Mivel csökkenthető az import földgáz? Magyar Energetika, 2, 18-21. http://magyarenergetika.hu/wp-content/uploads/me/ME\%202017-2.pdf 
MTA - MMK - MaTáSZSZ - MTT (2015): Települési hőellátás helyi energiával című konferencia állásfoglalása. Energiagazdálkodás, 56, 5-6, 62-63. http://termalenergia.hu/wp-content/uploads/2015/10/Konferencia-\%C3\%A111\%C3\%A1sfoglal\%C3\%A1s.pdf

Osvald M. - Szanyi J. - Medgyes T. et al. (2017): Geothermal Energy Developments in the District Heating of Szeged. European Geologist, 43, 30-33. https:/issuu.com/efgoffice/docs/ egj43_print

Szanyi J. - Kovács B. (2010): Utilization of Geothermal Systems in South-East Hungary. Geothermics, 39, 357-364. DOI: 10.1016/j.geothermics.2010.09.004, https://www.researchgate.net/ publication/222010593_Utilization_of_geothermal_systems_in_South-East_Hungary

Varga A. - Bozsó G. - Garaguly I. et al. (2019): Cements, Waters, and Scales: An Integrated Study of Thermal Water Chemistry and Its Role on Clastic Reservoir Diagenesis and Scale Precipitation in the Szeged Geothermal Systems, SE Hungary. Geofluids, Article ID 4863814, DOI: 10.1155/2019/4863814, https://www.hindawi.com/journals/geofluids/2019/4863814/ 